
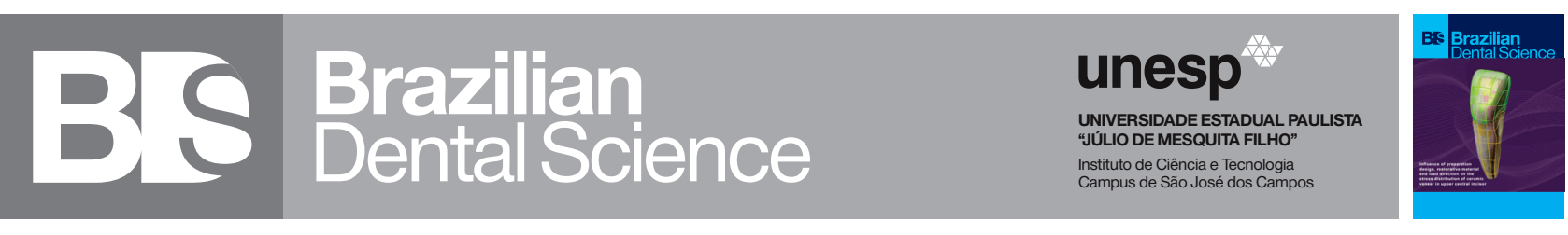

\title{
Effect of Thermo-Mechanical Aging and Repressing on Fracture Resistance of Lithium Disilicate Crowns
}

Efeito do envelhecimento termomecânico e reprensagem na resistência à fratura de coroas de dissilicato de lítio

\author{
Amr EL-ETREBY ${ }^{1}$, Mahmoud METWALLY', Gihan ELNAGGAR ${ }^{3}$ \\ 1 - Faculty of Dentistry, Ain Shams University, Cairo, Egypt. \\ 2 - Faculty of Oral and Dental Medicine, Future University in Egypt, Cairo, Egypt. \\ 3 - Faculty of Oral and Dental Medicine, Cairo University, Cairo, Egypt.
}

\section{ABSTRACT}

Objective: The recycling of heat pressed lithium disilicate glass-ceramic leftover material has been reported to be done by dental laboratories. The effect of this procedure on the fracture resistance of single crowns is unknown, especially when it is functioning inside the oral cavity with subsequent exposure to temperature changes and cycles of mastication. Material and Methods: A total of 28 lithium disilicate glass-ceramic crowns (IPS emax Press) were constructed and randomly assigned into two groups ( $\mathrm{n}=14)$; Group (P): Included crowns fabricated from new e.max ingots. Group (R): Included crowns fabricated from repressed e.max buttons. Specimens of each group were divided into two equal subgroups $(n=7)$ according to whether the aging of specimens will be performed or not before fracture resistance testing. Subgroup (N), samples were subjected to fracture resistance without thermo-mechanical aging, while subgroup (A), samples were subjected to thermo-cycling and cyclic loading before being subjected to fracture strength testing. Different methods; SEM, XRD, EDAX were used to characterize the properties of lithium disilicate glass-ceramics before and after repressing. Results: The highest statistically significant fracture resistance value was recorded for the subgroup (RN) repressed/ non-aged, followed by the subgroup repressed/ aged (RA), while the lowest statistically significant mean value was recorded for the subgroup pressed/aged (PA). There was no

\section{RESUMO}

Objetivo: A reutilização de material residual de vitrocerâmicas de dissilicato de lítio prensadas a quente tem sido realizada pelos laboratórios de prótese. O efeito deste procedimento na resistência à fratura de coroas unitárias é desconhecido, especialmente quando estão em função na cavidade oral com subsequente exposição às variações de temperatura e ciclos mastigatórios. Material e Métodos: Vinte e oito coroas de dissilicato de lítio (IPS e.max Press) foram confeccionadas e divididas aleatoriamente em dois grupos $(n=14)$; Grupo (P): Incluiu coroas fabricadas de pastilhas novas de e.max; Grupo (R): Incluiu coroas fabricadas de e.max reprensado. As amostras de cada grupo foram divididas em dois subgrupos iguais ( $n=7)$ de acordo com a realização de envelhecimento dos espécimes antes do teste de resistência à fratura. As amostras do subgrupo $(\mathrm{N})$ foram submetidas ao teste de resistência à fratura sem envelhecimento termomecânico, enquanto as amostras do subgrupo (A) foram submetidas ao envelhecimento termomecânico antes do teste de resistência à fratura. Diferentes métodos (MEV, DRX e EDS) foram usados para caracterizar as propriedades da cerâmica de dissilicato de lítio antes e depois da reprensagem. Resultados: O maior valor de resistência à fratura estatisticamente significativo foi do subgrupo $(\mathrm{RN})$ reprensado/não envelhecido, seguido pelo subgrupo reprensado/ envelhecido (RA), enquanto o menor valor médio estatisticamente significativo foi do subgrupo prensado/envelhecido (PA). Não houve diferença estatística entre os subgrupos prensado/não 
significant difference between pressed/nonaged (PN) and repressed/aged (RA) subgroups. Conclusion: Repressing of leftover buttons may increase the fracture resistance of IPS emax Press crowns. Thermo-mechanical aging may negatively affect the fracture resistance of IPS emax Press crowns, yet Repressing may decrease this effect. Clinical implications: This is a novel approach that targets a point of research that has not been investigated before. It elaborates how repressing may decrease the effect of aging and increase the fracture resistance of lithium disilicate crowns. Thus, recycling of lithium disilicate glass ceramics might decrease its failure and prolong their serviceability.

\section{KEYWORDS}

Fracture resistance; Heat pressed; Lithium disilicate; Recycling; Repressing; Thermomechanical aging. envelhecido (PN) e reprensado/envelhecido (RA). Conclusão: A reprensagem de material residual pode aumentar a resistência à fratura de coroas de IPS e.max Press. O envelhecimento termomecânico pode afetar negativamente na resistência à fratura deste material, enquanto a reprensagem pode diminuir este efeito. Relevância clínica: Esta é uma nova abordagem que busca estudar um tema que não havia sido investigado anteriormente. Este estudo demonstrou como a reprensagem pode diminuir o efeito do envelhecimento e aumentar a resistência à fratura de coroas de dissilicato de lítio. Assim, a reutilização de vitrocerâmicas de dissilicato de lítio pode diminuir o risco à falha e aumentar o tempo de vida útil.

\section{PALAVRAS-CHAVE}

Resistência à fratura; Prensagem a quente; Dissilicato de Lítio; Reciclagem; Reprensagem; Envelhecimento termomecânico.

\section{INTRODUCTION}

T eat-pressed glass-ceramic restorations 1 have evoked much interest due to their biocompatibility, excellent esthetics, and high mechanical properties [1-3]. Aging and stress fatigue in the oral environment affect the longevity of all-ceramic restorations when in function. Thermo-cycling may now be considered as one of the most acceptable methods to reproduce dynamic stresses. The sequence of temperatures: $350^{\circ} \mathrm{C}, 150^{\circ} \mathrm{C}, 350^{\circ} \mathrm{C}$, and then $450^{\circ} \mathrm{C}$, with a corresponding dwell sequence of 28 seconds, 2 seconds, 28 seconds, and 2 seconds, was suggested to be sufficiently clinically relevant. On the basis that such cycles might occur between 20 and 50 times in a day, it was proposed that 10000 cycles might represent a service year [4-8]. Fatigue is now recognized as either the primary mode of failure or a contributing mechanism in the failure of all-ceramic restorations. Several studies reported that the rapid rate of decline in the strength of a ceramic restoration leveled off after 10,000 cycles of dynamic loading and that
240,000 cycles are correspondent to 1 year of intra-oral service. [9-15]

Static loading to fracture is commonly used to indicate whether a material and restoration type can be considered as a viable clinical option. However, it only shows the strength of restorations immediately after bonding, so these fracture resistance values are not indicative of the restoration long-term success [16-18]. It has been demonstrated that the physiologic maximum occlusal forces may vary up to 500 Newton depending on facial morphology and age. Several studies reported that the mean loading force ranged from 50 to $250 \mathrm{~N}$, while during parafunctional movements such as bruxism and clenching the loads varied between 500 and $800 \mathrm{~N}$ with a maximum masticatory forces mean value encountered in the molar region for men are $847 \mathrm{~N}$ and $597 \mathrm{~N}$ for women [19-20]. In the oral cavity, restorations are loaded with millions of cycles during their lifetime, which can cause a significant reduction in the strength of the material due to fatigue. Studying fracture 
resistance under thermo-mechanical loading was reported to determine the success and longevity of a restoration [21-23].

Heat-pressing of lithium disilicate glassceramics utilizes the lost wax technique. This technique involves waxing of the restoration to the desired shape and contour, spruing and investing the wax pattern, wax elimination to create a mold within the investment using a burn-out furnace, pressing the molten ceramic at high temperature under high pressure and vacuum into the mold within a special furnace developed specifically for this product. After cooling of the investment mold the restoration is divested, then the ceramic restoration is cut from the sprue and both the remaining button and sprue are usually discarded, then the restoration is finished, polished, characterized and glazed before delivery [24,25]. From an economic point of view, dental labs try to press as many restorations every single time in an attempt not to waste more material but unfortunately, this is not possible every time. In some dental labs these residual or leftover materials (the remaining sprues and button) are found to be useful for repressing new restorations $[25,26]$.

A limited number of researches have investigated the effect of repressing the leftover material on the biaxial flexural strength of heat pressed glass-ceramics; Empress I and Empress II, [25] Optimal pressable glass-ceramic OPC, 3G, Empress I and Empress II, [27] IPS e.max Press. [26] They concluded that the repressing had no significant effect on the biaxial flexural strength of glass ceramics $[25,26]$ in contrast to others who concluded that repressing produced a statistically significant in $\neg$ crease in the flexural strength of repressed glass-ceramic material [27]. Hardness and flexural toughness were also investigated and the results showed no significant difference between tested groups [26]. X-ray diffraction was used to characterize the crystalline phase, scanning electron microscopy for the microstructure and no difference in crystalline composition was found with repeated pressing. Finally, it was concluded that lithium disilicate glass-ceramic can be repressed while maintaining good mechanical properties and without significantly altering the crystalline composition. [25-27]

However, another study found that the density of lithium disilicate ceramics (IPS e.max Press) decreased and porosity increased after two heat pressing events. Also flexural strength, Vickers hardness, and fracture toughness significantly decreased. Finally, they concluded that repeated heat-pressing was detrimental to the density, porosity, strength, hardness, and toughness of IPS e.max Press. [28] Regarding mechanical properties, fracture resistance of restorations fabricated from repressed lithium disilicate material, and the effect of aging on it has not been yet investigated. The present study aimed to evaluate the effect of repressing and thermo-mechanical aging on the fracture resistance of lithium disilicate glass-ceramic crowns (IPS e.max press). The null hypothesis was that repressing and thermo-mechanical aging would have no significant effect on the fracture resistance of lithium disilicate crowns.

\section{MATERIALS AND METHODS}

Sample size: The power analysis used fracture resistance values obtained from a pilot study by using three samples in each group as the primary outcome. Power analysis was conducted for a 2 x 2 fixed-effects analysis of variance. The first factor (Method of crown fabrication) includes two levels and the second factor (Aging) includes two levels. Based upon the results of the pilot study; the effect size (f) for the first factor was found to be (0.6) and for the second factor (f) was (0.72). Using alpha ( $\alpha$ ) level of $(5 \%)$ and Beta $(\beta)$ level of $(20 \%)$, power $=(80 \%)$; the minimum estimated sample size was (7) samples per cell giving a total of (28) samples. Samples used in the pilot study were included in the final analysis. Sample size calculation was performed with IBM SPSS, SamplePower, Release 3.0.1.

2.1. Specimen preparation: A lower first molar prototype was mounted in acrylic resin base with the aid of a surveyor (Acrostone, Ramses Co.). A computerized numerical control (C.N.C premium 4820, imes-icore) lathe-cut 
milling machine was used to prepare the tooth to receive a lithium disilicate posterior crown (1.5 $\mathrm{mm}$ occlusal and axial reduction, $1 \mathrm{~mm}$ shoulder finish line). According to the manufacturer instructions, the master dies were duplicated with a silicon duplicating material (Replisil 22N, dentecon). After setting, the mold was poured with chemical cure epoxy resin (Chemapoxy 150, MBC) and left for 24 hours to ensure complete curing, and then each die was examined under (2.5x) magnifying loops for any imperfections.

A total of 28 lithium disilicate glass-ceramic crowns were randomly assigned into two groups; Group (P) Pressed: Included crowns fabricated from new e.max ingots. ( $n=14)$. Group (R) Repressed: Included crowns fabricated from repressed e.max buttons. $(n=14)$. Specimens of each group were divided into two equal subgroups $(n=7)$. Subgroup $(N)(n=7)$, crowns were subjected to fracture resistance without thermo-mechanical aging, while subgroup (A) (n $=7$ ), crowns were subjected to thermo-cycling and cyclic loading before being subjected to fracture strength testing. For standardization of the crowns anatomy, contour, and thickness, and to omit all operator variables involved in the fabrication process, a 5-axis milling machine (VHF CAM 5-S1, VHF), a desktop computer connected to Identica blue scanner (MEDIT corp.) and an Exocad computer software version 2017.[12] (Exocad $\mathrm{GmbH}$ ) were used for indirect fabrication of crowns wax pattern (Dima Mill Wax, KULZAR). [29,30]

All milled wax patterns were tried gently over their corresponding dies to check for their accuracy, fit and marginal adaption under (2.5x) magnification and any defective wax pattern was discarded. All wax patterns were sprued and invested following manufacturer instruction with IPS PressVEST (Ivoclar Vivadent). The investment was left to set for 30 minutes, and then wax elimination was performed with wax burn out furnace (Ney, US Dental) according to the manufacturer's recommendation. Crowns of Group (P) were pressed following manufacturer's recommendations in a heat press furnace (EP 3000, Ivoclar Vivadent) by using new IPS emax ingots. Crowns were retrieved from the investment ring using air abrasion with alumina particles $110 \mu \mathrm{m}$ (Cobra, Renfert) under 4 bar pressure (Rough divesting) then under 2 bar pressure (Soft divesting). The pressed crowns were then immersed for 10 minutes in 1\% hydrofluoric acid Invex liquid (Ivoclar Vivadent) to remove the reaction layer of the investment followed by the aid of another soft divesting cycle. The crowns were cut from the sprues and the remaining buttons from the pressing process were finished in a way to resemble the shape of a new IPS e.max Press ingot using diamond discs and stones. For the fabrication of Group (R) specimens, the previously mentioned trimmed leftover buttons were used instead of new ingots. All IPS e.max Press crowns of both groups were finished then glazed according to the manufacturer instructions.

The internal surface of the restorations was etched with buffered hydrofluoric acid gel 9.5\% (Porcelain Etchant, BISCO) for 20 seconds, rinsed with water, and then dried with oil-free moisture-free air. Silane coupling agent (Porcelain Primer, Prehydrolyzed Silane, BISCO) was applied to every internal surface of all restorations for 1 minute, then air-dried for 5 seconds. All epoxy dies were acid-etched for 15 seconds, rinsed with water, air-dried followed by the application of adhesive (Single Bond Universal, 3M, ESPE), and then light-cured for 20 seconds. before cementation. Crowns were cemented using translucent dual-cured selfadhesive resin cement (Breeze, Pentron Clinical). Using gentle finger pressure the crowns were seated on their corresponding dies. Excess luting material was removed with a brush and then an axial load of $5 \mathrm{~kg}$ was applied for 10 minutes. The luting material was light cured for 20 seconds per surface using SDI radii plus light-curing unit. The margins were then covered with air barrier gel (K-Y Jelly, Johnson \& Johnson) and light-cured for an additional 20 seconds. [31]

2.2. Thermocycling: all specimens were subjected to 5000 cycles which corresponds to 6 months of intraoral service, Dwell times were 25 seconds in each water bath (Robota automated 
thermal cycle; BILGE) with a lag time 10 seconds. The low-temperature point was $5{ }^{\circ} \mathrm{C}$, the hightemperature point was $55^{\circ} \mathrm{C} .8,[16]$

2.3. Cyclic loading: was performed with a ROBOTA chewing simulator. All chewing parameters used are presented in (Table I). The test was repeated 120,000 cycles of chewing (simulating a 6 months of intraoral loads).[11]

Table I - Chewing Parameters

\begin{tabular}{|cc|}
\hline \multicolumn{2}{|c|}{ Chewing simulator parameters } \\
\hline Vertical movement: $1 \mathrm{~mm}$ & Horizontal movement: $3 \mathrm{~mm}$ \\
\hline Rising speed: $90 \mathrm{~mm} / \mathrm{s}$ & Forward speed: $90 \mathrm{~mm} / \mathrm{s}$ \\
\hline Descending speed: $40 \mathrm{~mm} / \mathrm{s}$ & Backward speed: $40 \mathrm{~mm} / \mathrm{s}$ \\
\hline Cycle frequency $1.6 \mathrm{~Hz}$ & Weight per sample: from $3 \mathrm{~kg}$ \\
\hline & Torque: $2.4 \mathrm{N.m}$ \\
\hline
\end{tabular}

2.4. Fracture Resistance: A universal testing machine (Lloyd Instruments Ltd.) with a load cell of $5 \mathrm{~kg}$ was used. The fracture test was done by a compressive mode of load applied to the center of the occlusal surface. A metallic rod with a spherical tip (5.6 mm diameter) that touched only the inclined planes of buccal and lingual cusps, traveling at a cross-head speed of 1 $\mathrm{mm} /$ minute and attached to the upper movable compartment of the testing machine was used. For proper stress distribution, a tin foil sheet was placed between the occlusal surface of the crown and the applicator tip. Failure load (audible crack sound and a sharp drop at the load-deflection curve) and the fracture mode were recorded in Newton.

2.5. Scanning electron microscopy (SEM): The fitting surface of each crown was cleaned and etched for 90 seconds with 9.8\% Hydrofluoric acid, cleaned in an ultrasonic cleaner, steamed, then dried and sputter gold coated. Scanning electron microscopy (Quanta 250 FEG) was carried out at magnification of $6000 \mathrm{x}$

2.6. X-ray diffraction analysis (XRD): Samples were placed on the holder of the diffractometer (X pert pro; PW 3040/60) and scanned using $\mathrm{Cu} \mathrm{Ka}$ x-ray angle from 20-40 degrees, $2 \theta$ with a step size of 0.04 degrees and 5 seconds-step interval.

2.7. Energy Dispersive $\mathrm{x}$-ray analysis (EDAX): For each group, EDAX was carried out to quantify elements by X-ray microanalysis (FEI Czech SEM ).

Data were collected and presented in terms of mean, standard deviation (SD), and range (Min-Max) for values. Graph Pad Instat (Graph Pad, Inc.) software for windows were used, and statistical significance was considered if a value of $p<0.05$. A two-way analysis of variance was performed to detect the effect of each variable after homogeneity of variance, and normal distribution of errors had been confirmed. Student t-test was done for compared pairs.

\section{RESULTS}

3.1. Effect of thermo-mechanical aging on fracture resistance: Irrespective of the type of processing technique (Pressed and Repressed), it was found that there was a statistically significant difference between the fracture resistance as a function of thermo-mechanical aging. Non-aged subgroup $(\mathrm{N})$ recorded higher fracture resistance values $(1634.49 \pm 123.36 \mathrm{~N})$ than the Aged subgroup (A) $(1514.38 \pm 127.27 \mathrm{~N})$ at $\mathrm{p}<0.05$.

3.2. Effect of Repressing on fracture resistance: Regardless of thermo-mechanical aging, there was a statistically significant difference between the fracture resistance of studied groups, where the Repressed group (R) recorded higher fracture resistance values $(1653.113 \pm 56.84 \mathrm{~N})$ than Pressed group $(\mathrm{P})$ $(1495.765 \pm 63.27 \mathrm{~N})$ at $\mathrm{p}<0.05$.

3.3. Effect of Thermo-mechanical aging and Repressing on fracture resistance (variables interaction): Descriptive statistics of fracture resistance in Newton showing mean, standard deviation (SD), minimum, maximum and 95\% confidence intervals (low and high) values for both groups as a function of thermo-mechanical aging are summarized in (Table II) and graphically drawn in (Figure 1). Results showed a statistically significant difference between tested groups at $\mathrm{p}<0.05$, where the highest 
statistically significant fracture resistance value was recorded for the subgroup ( $\mathrm{RN}$ ) repressed/ non-aged $(1709.95 \pm 73.06 \mathrm{~N})$. The second significantly higher value was recorded for the subgroup repressed/aged (RA) (1596.28 \pm 106.9 $\mathrm{N})$. While the lowest statistically significant mean value was recorded for the subgroup pressed/ aged (PA) (1432.49 \pm 82.3) as indicated by ANOVA test at $\mathrm{p}<0.05$. Pair-wise Tukeys posthoc test showed non-significant difference ( $\mathrm{p}>$ 0.05) between pressed/non-aged (PN) (1559.03 $\pm 117.5)$ and repressed/aged (RA) (1596.28 \pm 106.9) subgroups.

Table I - Descriptive statistics of fracture resistance results (Mean values \pm SDs) for both groups as function of thermomechanical aging

\begin{tabular}{|c|c|c|c|c|c|c|c|}
\hline \multirow{2}{*}{\multicolumn{2}{|c|}{ Variables }} & \multirow{2}{*}{$\begin{array}{c}\text { Mean } \pm \\
\text { SD }\end{array}$} & \multirow{2}{*}{ Min. } & \multirow{2}{*}{ Max. } & \multicolumn{2}{|c|}{$95 \% \mathrm{Cl}$} & \multirow{2}{*}{$\begin{array}{c}\text { Statistics } \\
\text { p value }\end{array}$} \\
\hline & & & & & Low & High & \\
\hline \multirow[t]{2}{*}{$\begin{array}{l}\text { Pressed } \\
(\mathrm{P})\end{array}$} & $\begin{array}{l}\text { Non- } \\
\text {-aged } \\
\text { (N) }\end{array}$ & $\begin{array}{c}1559.03^{B} \\
\pm 117.5\end{array}$ & 1318.47 & 1841.36 & 1450.4 & 1667.7 & \multirow[t]{2}{*}{$0.0378^{\star}$} \\
\hline & $\begin{array}{l}\text { Aged } \\
\text { (A) }\end{array}$ & $\begin{array}{c}1432.49^{c} \pm \\
82.3\end{array}$ & 1262.1 & 1681.4 & 1356.4 & 1508.6 & \\
\hline \multirow[t]{2}{*}{$\begin{array}{l}\text { Repres- } \\
\text { sed } \\
\text { (R) }\end{array}$} & $\begin{array}{l}\text { Non- } \\
\text {-aged } \\
\text { (N) }\end{array}$ & $\begin{array}{c}1709.95^{A} \pm \\
73.06\end{array}$ & 1559.5 & 1927 & 1642.4 & 1777.5 & \multirow[t]{2}{*}{$0.0386^{*}$} \\
\hline & $\begin{array}{l}\text { Aged } \\
\text { (A) }\end{array}$ & $\begin{array}{c}1596.28^{B} \pm \\
106.9\end{array}$ & 1406 & 1840 & 1497.4 & 1695.2 & \\
\hline
\end{tabular}

Different superscript capital letter indicating significance $(p<0.05)$ *; significant $(p<0.05)$

ns; non-significant $(p>0.05)$

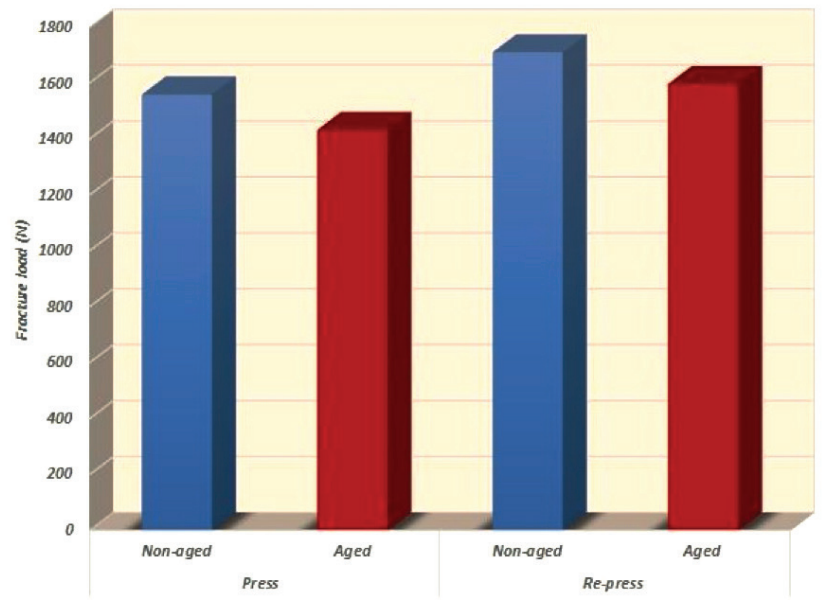

Figure 1- Column chart of fracture resistance mean values for both groups before and after thermo-mechanical aging.
3.4. Mode of failure of fractured samples: Failure modes were observed and classified into 3 groups (Table III): Type I: Cracking, Type II: Chipping or partial fracture, and Type III: Catastrophic or fragmented fracture.

Table III - Frequent distribution of failure modes recorded for all groups

\begin{tabular}{|ccccc|} 
& \multicolumn{2}{c}{ Pressed (P) } & \multicolumn{2}{c|}{ Repressed(R) } \\
\cline { 2 - 5 } & Non-aged(N) & Aged(A) & Non-aged(N) & Aged(A) \\
\hline Type I & $66.7 \%$ & $0 \%$ & $33.3 \%$ & $0 \%$ \\
\hline Type II & $0 \%$ & $33.3 \%$ & $0 \%$ & $33.3 \%$ \\
\hline Type III & $33.3 \%$ & $66.7 \%$ & $66.7 \%$ & $66.7 \%$ \\
\hline
\end{tabular}

3.5. Scanning electron microscopy: The SEM (Quanta 250 FEG) image observations $(6000 \mathrm{x})$ showed that there is a noted increase in dimension of lithium disilicate crystals after repressing; in pressed specimens, the length of lithium disilicate crystals averaged $3.05 \mu \mathrm{m}$ in length while they averaged $473 \mathrm{~nm}$ in width, compared to repressed that averaged $6 \mu \mathrm{m}$ in length while they averaged $500 \mathrm{~nm}$ in width and showing increased interlocking than the pressed samples (Figure 2 and 3).

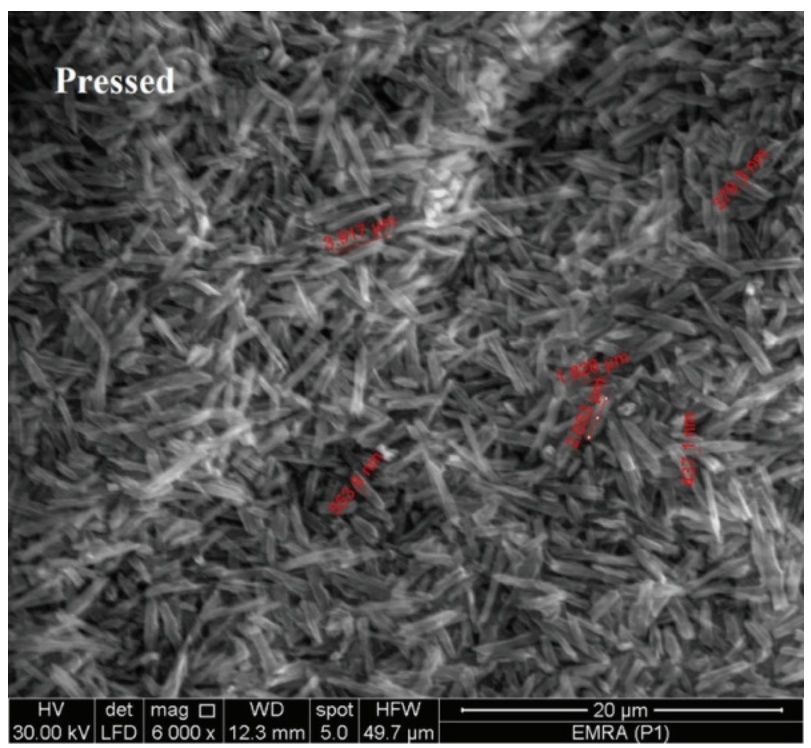

Figure 2 - SEM of IPS e.max Press (Pressed). 


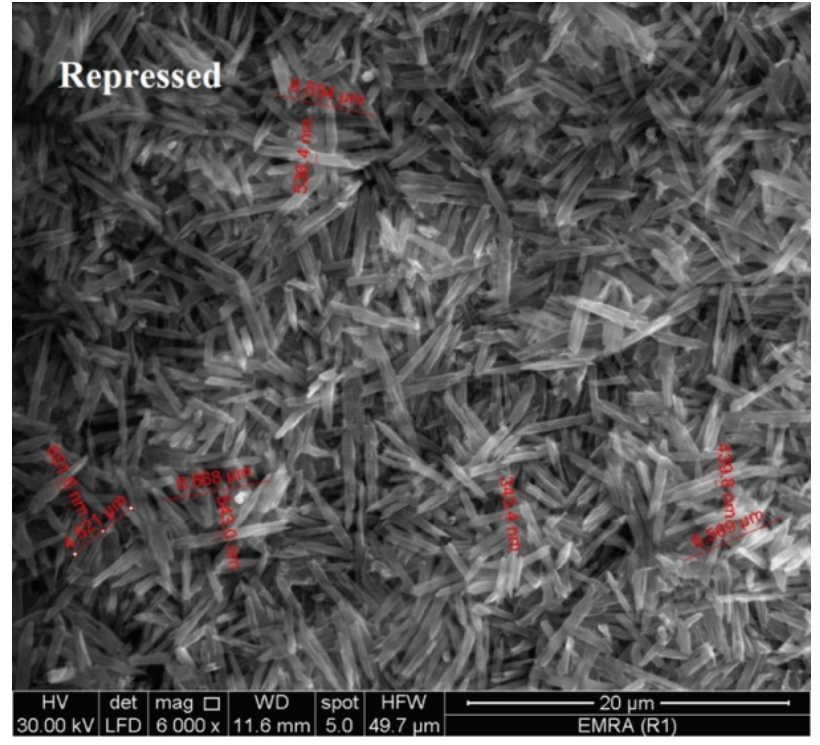

Figure 3 - SEM of IPS e.max Press (Repressed).

3.6. X-ray diffraction analysis: The X-ray analysis of both pressed and repressed samples showed that the material is predominantly crystalline structure; lithium disilicate was identified as the main crystalline phase (Figure 4 and 5).

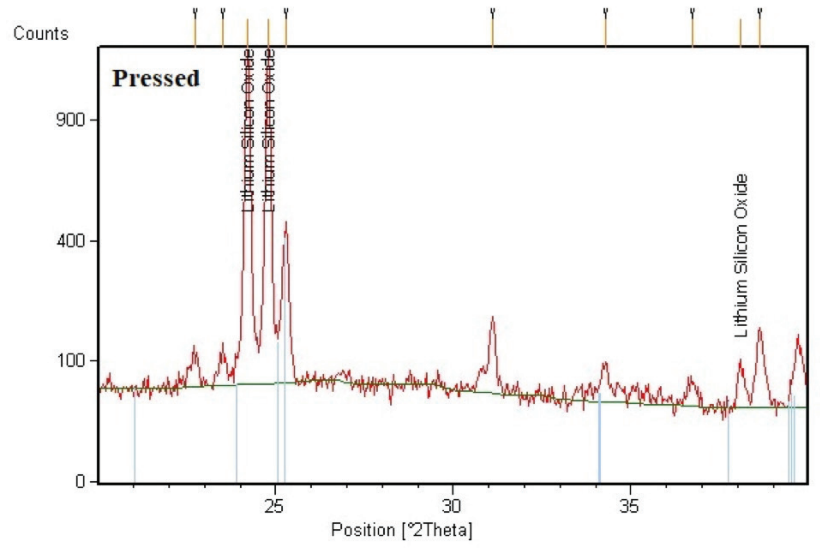

Figure 4 - X-ray diffraction (XRD) patterns of IPS e.max Press (Pressed) showing peak positions in agreement with those of standard Lithium disilicate.

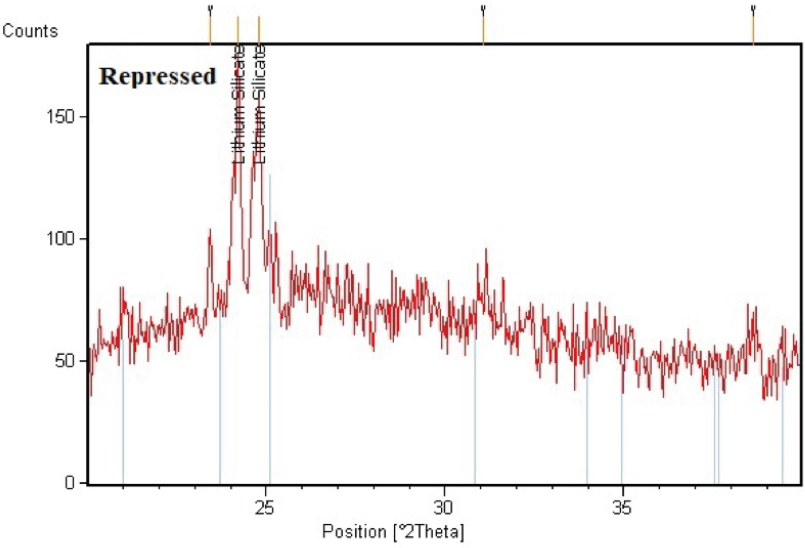

Figure 5 - X-ray diffraction (XRD) patterns of IPS e.max Press (Repressed) showing peak positions in agreement with those of standard Lithium disilicate.

3.7. Energy Dispersive x-ray analysis: EDAX results showed no change in composition between pressed and repressed samples (Figure 6 and 7).
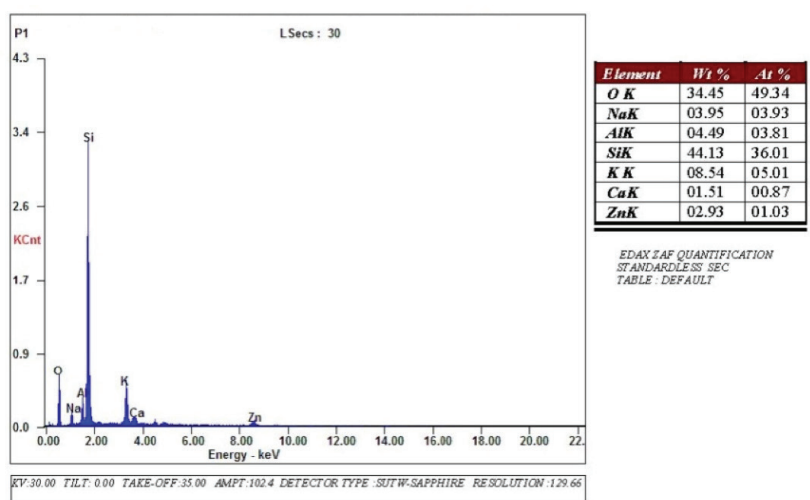
EDAX ZAF QUAANIFFCATION
TANDARDESS SEC
TABLE: DEFAULIT

Figure 6 - Microanalysis by EDAX of IPS e.max Press (Pressed).

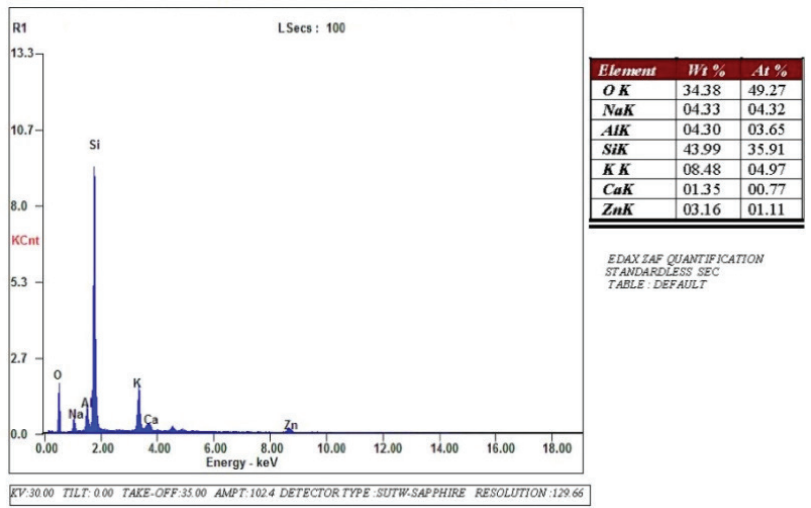

Figure 7 - Microanalysis by EDAX of IPS e.max Press (Repressed). 


\section{DISCUSSION}

In the present study, the null hypothesis was rejected as the fracture resistance of lithium disilicate glass-ceramic crowns increased with repressing. Also, thermo-mechanical aging reduced the fracture resistance of repressed specimens.

The SEM images of both groups (Pressed and Repressed) showed that the crystal size of lithium disilicate glass-ceramic (IPS emax) showed a noted increase in length after repressing, and this may be explained by Ostwald ripening; large crystals grow on the expense of the small ones. [25] The X-ray analysis of both pressed and repressed samples showed that the material is predominantly crystalline structure; lithium disilicate was identified to be the main crystalline phase and this was in agreement with the results of Chung et al., and Albakry et al. $[25,27]$.

Regarding the effect of repressing, in the non-aged subgroups, the repress group had statistically significant higher fracture resistance mean value than press group. This may be due to the interlocking microstructure of the densely packed lithium disilicate crystals. These results coincide with the findings of Albakry et al. [25] who attributed the improved mechanical properties of lithium disilicate ceramic material to the preferred orientation of the crystals that occur after pressing and cause fracture toughness anisotropy.

Regarding the effect of aging, a reduction in fracture resistance was encountered after thermo-mechanical aging, which could be attributed to the effect of thermo-cycling. A mismatch between the crystal contents and the glassy matrix coefficient of thermal expansion may have led to thermal stresses at the crystalmatrix interface causing a micro-crack formation and resulting in decreasing the strength, this goes in agreement with Guess et al. [22].This also coincide with Barcellos et al. [23] who found significant differences on lithium disilicate strength depending on the type of aging. They attributed this to the presence of a bi-phase structure which during temperature variations showed different thermal contractions causing internal stresses and a subsequent decrease in strength. In the aged subgroup of the current study, results showed that repress group recorded statistically significant higher fracture resistance mean value than the press group. This could be attributed to the effect of repressing, which may have created a microstructure with fewer defects. [24] In the current study for all tested groups, the mean fracture loads were far beyond the mean reported maximum masticatory forces. Therefore, the tested specimens might be able to withstand the maximum posterior masticatory forces.

\section{LIMITATIONS OF THE STUDY}

The effect of more than one pressing cycle as well as shear bond strength of resin cement to repressed lithium disilicate glass-ceramics were not investigated

\section{CONCLUSION}

1 - Repressing of leftover buttons may increase the fracture resistance of IPS emax Press crowns.

2 - Thermo-mechanical aging may negatively affect the fracture resistance of IPS emax Press crowns.

3 - Repressing may decrease the effect of aging on the fracture resistance of Lithium disilicate IPS emax Press crowns.

\section{RECOMIMNDATIONS}

1 - Lithium disilicate restorations may be suggested to a tempering cycle before final cementation.

2 - Further investigation regarding the exact temperatures of this tempering cycle with a recommendation that it should be near to the repressing temperature. 


\section{REFERENCES}

1. Daswani SR, Aras MA, Chitre V, Rajagopal P.Dental ceramics: material options and clinical recommendations. J Adv Med Dent Sci. 2014;2:67-73.

2. Rama A. Dental materials science. New Delhi: India: Jaypee Brothers Medical Publishers Pvt Limited;2013. p.333-54.

3. Helvey GA. A history of dental ceramics. Compend Contin Educ Dent. 2010;31:1-3.

4. Drummond JL.Ceramic behavior under different environmental and loading conditions., Chicago: Quintessence Publ; 2003. p35-45.

5. Mazzitelli C,Monticelli F, Toledano M,Ferrari M, Osorio R. Effect of thermal cycling on the bond strength of self adhesive cements to fiber posts. Clin. Oral Invest, 2012; 16:909-15.

6. Özel Bektas Ö, Eren D, Herguner Siso S, Akin GE. Effect of thermocycling on the bond strength of composite resin to bur and laser treated composite resin. Lasers Med Sci. 2012;27:723-8.

7. Morresi AL, D'Amario M, Capogreco M, Gatto R, Marzo G, D'Arcangelo C, et al. Thermal cycling for restorative materials: does a standardized protocol existin laboratory testing? a literature review. J Mech Behav Biomed Mater. 2014;29:295-308.

8. Galea MS, Darvellb BW. Thermal cycling procedures for laboratory testing of dental restorations: review. J Dent1999;27:89-99.

9. Arola D. Fatigue testing of biomaterials and their interfaces. Dent Mater. 2017;33:367-81.

10. Chen HY, Hickel R, Setcos JC, Kunzelmann KH. Effects of surface finish and fatigue testing on the fracture strength of CAD-CAM and pressed-ceramic crowns. JProsthet Dent. 1999;82:468-75.

11. Steiner CM, Mitsias ME, Ludwig K, Kern M. In vitro evaluation of a mechanical testing chewing simulator. Dent Mater. 2009;25:494-9.

12. Abou-Madina M, Abdelaziz K. Influence of different cementation materials and thermocycling on the fracture resistance of IPS e.max press posterior crowns. Int JDent Sci. 2008;6:1-7.

13. Wang RR, Lu CL, Wang G, Zhang DS. Influence of cyclic loading on the fracture toughness and load bearinf capaciyies of all-ceramic crowns. Int J Oral Sci. 2014 Jun;6:99-104.

14. Yildirim G. Fracture resistance of CAD-CAM ceramic crowns: an in vitro analysis. SF Dent Oral Res J.2017,:3.

15. Gungor M, Nemli K. Fracture resistance of CAD-CAM monolithic ceramic and veneered zirconia molar crowns after aging in a mastication simulator. J Prosthet Dent. 2018;119:473-80.

16. Stewardson DA, Shortall AC, Marquis PM. The effect of clinically relevant thermocycling on flexural properties of endodonticpost materials. J Dent,2010; 38:437-42.
17. Rosentritt M,Plein T,Kolbeck C. In vitro fracture force and marginal adaptation of ceramic crowns fixed on natural and artificial teeth. Int J Prosthodont. 2000;13:387-91.

18. Sarafidou K, Stiesch M, Dittmer MP, Jorn D, Borchers L, KohorstP.Loadbearing capacity of artificially aged zirconia fixed dental prostheses with heterogeneous abutment supports. Clin Oral Investig. 2012;16:961-8.

19. Killiaridas $S$, Wenneberg $B$, Engstrom $C$. The relationship between maximal bite force, bite force endurance and facial morphology during growth. Acta. Odont. Scand. 1993;51:323-31.

20. Haraldson T, Carlsson GE, Ingervall B. Functional state, bite force and postural muscle activity in patients with osseointegrated oral implant bridges. Acta Odont. Scand.1979;37:195-206.

21. Magne P,Knezevic A. Stimulated fatigue resistance of composite resin versus porcelain CAD/CAM overlay restorations on endodontically treated molars. Quint Int.2009;40:125-33.

22. Guess PC, Schultheis S, BonfanteEA, Coelho PG, Ferencz JL, Silva NR. Allceramic systems: laboratory and clinical performance. Dent Clin North Am. 2011:55:333-52.

23. Barcellos ASP, Marinho CC, Miranda JS, Amaral M, Shiino MY, KimparaET. Effect of fatigue protocols on flexural strength of lithium disilicate bars with clampedends. J Mech Behav Biomed Mater. 2018;81:173-7.

24. Oliveira A, Serrado de Pinho A, Barcellos, Melo R. Can heat-pressed feldspathic ceramic be submitted to multiple heat-pressing? Braz. Oral Res. 2018;32:10613.

25. Albakry M, Guazzato M, Swain MV. Biaxial flexural strength and microstructure changes of two recycled pressable glass ceramics. J Prosthod. 2004; 13:141-9.

26. Gorman C,Horgan K, Dollard R, Stanton K. Effects of repeated processing on the strength and microstructure of a heat-pressed dental ceramic. JProsthet Dent 2014;112:1370-6.

27. Chung KH, Liao JH, Duh JG, Chan C. The effects of repeated heat-pressing on properties of pressable glass-ceramics. J Oral Rehabil. 2009;36:132-41.

28. Tanga $X$, Tanga C, Su H, Luo H, Nakamura T, Yatani $H$. The effects of repeated heat-pressing on the mechanical properties and microstructure of IPS e.max Press. J Mech Behav Biomed Mater. 2014;40:390-6.

29. Beuer F,Schweiger J,Edelhoff D. Digital dentistry: an overview of recent developments for CAD/CAM generated restorations. Br Dent J. 2008;204:50511.

30. Orsi IA, Varoli FK, Pieroni CH, Ferreira MC, Borie E. In vitro tensile strength of luting cements on metallic substrate. Braz Dent J. 2014;25:136-40.

31. Passi P,Girardello $G$, Vesentini A. Resistance to fracture of ceramic jacket crowns. Quint. Int 1992;23:845-7.

\section{Amr EL-Etreby}

Date submitted: 2020 0ct 5

Email: prof.amreletreby@gmail.com
Accept submission: 2020 Dec 17 